\title{
Tracing the Space Between Euphemisms and Dysphemisms: The Case of Obesity in English and German
}

\begin{abstract}
The paper investigates how obesity as an aspect of physical appearance is represented in English and German. The existence of various expressions that refer to obesity leads to the assumption that both investigated languages rely on euphemisms and dysphemisms to talk about obesity. Using a corpus of different expressions from lexicographic sources, we analyze their descriptions and their classification as euphemisms in specialized and general dictionaries. Semantic phenomena that might be identified within such expressions were also taken into consideration. To investigate the usage of the identified euphemisms and dysphemisms, a questionnaire was administered among native speakers of English and German. The corpus was used to trace the space between euphemisms and dysphemisms in language use. The main goal was to identify the ways in which obesity is referred to in two different sociocultural contexts, and to establish the extent to which lexicographic identifications and descriptions of euphemisms overlap with native speakers' perceptions and use of such items.
\end{abstract}

Keywords: euphemisms; dysphemisms; obesity; English; German

\section{Razmejitev prostora med evfemizmi in disfemizmi: Primer prekomerne teže $v$ angleščini in nemščini}

\section{POVZETEK}

V prispevku raziščemo, kako je prekomerna teža kot del zunanjega videza predstavljena $\mathrm{v}$ angleščini in nemščini. Ker $\mathrm{v}$ obeh jezikih obstajajo različni izrazi za prekomerno težo, predpostavljamo, da opisujeta ta vidik zunanjosti tako z evfemizmi kot z disfemizmi. S pomočjo korpusa izrazov iz leksikografskih virov analiziramo opise teh izrazov in njihovo klasifikacijo med evfemizme $\mathrm{v}$ specializiranih in splošnih slovarjih. Opazujemo tudi semantične pojave, ki jih najdemo med proučevanimi izrazi. Da bi razkrili rabo identificiranih evfemizmov in disfemizmov, uporabimo vprašalnik za rojene govorce angleščine in nemščine. $S$ korpusom razmejimo prostor med evfemizmi in disfemizmi v jezikovni rabi. Glavni cilj je opredeliti izraze, ki se v dveh različnih sociokulturnih kontekstih nanašajo na prekomerno težo, in ugotoviti, v kolikšni meri se leksikografske oznake in opisi evfemizmov prekrivajo s percepcijo teh izrazov med rojenimi govorci.

Ključne besede: evfemizmi; disfemizmi; prekomerna teža; angleščina; nemščina 


\section{Introduction}

Euphemisms represent a very productive area of linguistic analysis, and this is particularly evident in the analyses of euphemisms used to avoid the direct mention of what is considered to be an unpleasant or embarrassing concept in a given sociocultural context. Some areas of human experience, such as religion or death, have traditionally been euphemised. Besides these, there are many other areas that reveal characteristics of euphemistic usage in a specific community at a given point in time. As Sawerschel (2001, 18-19) points out, euphemisms are used to avoid an unpleasant, ominous or offensive issue because of religious reasons, shame or decency. In such cases, social norms and conventions play a decisive role. For example, age seems to have become a taboo in our time, so old people are referred to as 'not young anymore' or 'seniors' ("Senioren, Betagte, nicht mehr Junge"). Also, out of courtesy, instead of using the offensive 'fat' to refer to a woman, 'full-figured', 'plump' or 'stout' ("vollschlank, mollig oder wohlbeleibt") are used. Whether these words are taken as euphemisms or merely synonyms depends on the context they are used in.

This paper deals with euphemisms related to obesity as a particular aspect of physical appearance, as identified by R. W. Holder (2002). Holder's dictionary contains English euphemisms, and the corpus in this paper also consists of German euphemisms related to obesity. German euphemisms were retrieved from other sources since no specialized dictionary of German euphemisms was available. A special focus is placed on descriptions of euphemisms from the lexicographic point of view by comparing their classification as euphemisms in a specialized dictionary of euphemisms to the treatment of such items in a general dictionary. Although categorized as euphemisms, the investigation of the analysed items reveals that the space between euphemisms and dysphemisms may be vague. A reference is also made to semantic phenomena that might be identified within such expressions. Finally, a questionnaire was administered among native speakers of English and German. The aim of this part of the research is to use the corpus in order to trace the space between euphemisms and dysphemisms - the two concepts discussed at length by scholars such as Keith Allan and Kate Burridge (1991) and Eliecer Crespo Fernández (2007). Therefore, besides the analysis of the ways in which obesity is referred to in two different sociocultural contexts, the research aims to compare lexicographic identifications and speakers' use of euphemisms. By doing so, it is possible to evaluate the extent to which lexicographic identifications and descriptions of euphemisms overlap with native speakers' perceptions and use of such items, primarily in terms of distinguishing between items that are perceived as euphemisms and those perceived as dysphemisms.

Euphemisms may be viewed as a means of avoiding the use of linguistic expressions considered to be a taboo. Schröder (2013) deals with taboo words - those which are often avoided because they evoke unpleasant, dangerous or offensive thoughts. Lexical items that refer to certain taboo parts of the body and which should be replaced with other expressions are well-known. The replacement of taboo words in language is dealt with by Pieper (1991), who notes that people have the need to talk about taboo topics and always find a way to do so, and that linguistic taboos reflect both a specific time and any sociocultural changes that are occurring. 
In research on euphemistic expressions a substantial focus is placed on investigating the structural characteristics and semantic changes that occur in such expressions. Strategies of avoiding taboos can be found on all levels (phonemic, morphological, lexical, and syntagmatic), and can include, for example, changing the taboo form, ellipsis, saying the opposite of what one means, using diminutives or general forms (Pieper 1991, 5-6). It is tempting to hypothesize that euphemisms in other languages might exhibit a greater overlap in the area of semantic change and that the structural characteristics might exhibit this to a lesser degree due to differences in the formation patterns available in a given language. In the classification of strategies that are used to create euphemisms, Kate Burridge (2012) distinguishes and discusses at length a range of phenomena that fall under the following three broad categories: analogy, distortion, and borrowing. The author puts forward English examples and states that "they illustrate universal processes", but also adds the following: "All of these devices figure strongly in the formation of X-phemism across the languages of the world to a greater or lesser extent" (Burridge 2012, 72-73). ${ }^{1}$ It seems that the analysis of reasons why languages differ in the extent to which they make use of the different processes to create euphemisms deserves special attention. ${ }^{2}$

According to Havers (1946, 117-50), taboos were known early on - even Aryan knew them, and he gave the typology of substitutes: changes of sounds, loanwords, antiphrasis, substitutional pronouns, euphemistic blendings, paraphrase, ellipsis, and generalization.

\section{Euphemisms and Dysphemisms as Partial Synonyms and Indicators of Sociocultural Changes}

The question of whether absolute synonyms exist or not has been a matter of frequent discussions among scholars. However, even more attention has been paid to identifying the different ways in which synonyms in a given language differ and can, therefore, be regarded as partial synonyms. One of the ways in which they differ refers to stylistic differences, i.e., different stylistic forms and levels of formality. For example, in discussing partial synonyms, i.e., ways in which synonyms can differ, Palmer (1981, 60-61) refers, among other aspects, to differences in 'styles' or 'registers', and discusses them with reference to colloquial and 'posh' expressions as well as in terms of different degrees of formality. Similarly, in discussing the ways in which the meanings of propositional synonyms differ, Cruse (2000) mentions certain aspects of non-propositional meaning, including stylistic differences. Stylistic differences are identified as those that occur "on the colloquial-formal dimension" (Cruse 2000, 158).

See also Warren (1992) regarding the ways of constructing euphemisms.

Such topics have been analyzed in other languages as well, including Croatian. In the analysis of the linguistic strategies used to create Croatian euphemisms as identified in Anićs Dictionary, Pasini (2005, 64) mentions the following: metaphor; word extension and shortening; generic for specific and specific for generic (metonymy and synecdoche); hyperbole and litotes; and borrowing from other languages. Kuna (2007, 107-10) identifies the following semantic changes, i.e., rhetorical figures involved in the creation of Croatian euphemisms: metaphor, metonymy (including antonomasia), periphrasis, and antiphrasis. The overview of the semantic changes is preceded by a presentation of other processes included in the creation of Croatian euphemisms, and these include: phonetic-syllabic changes (further subdivided into five subcategories), different formation processes (including suffixation, prefixation, and compounding), and lexical means (modification, pronominalization, borrowing foreign words, neologization or assigning a new meaning to a word, and dropping of words (Kuna 2007, 104-7). 
The question that arises here is whether and to what extent euphemisms and dysphemisms can be regarded as partial synonyms. Firstly, the identification of euphemism as a particular type of synonym has already been explicitly attested (cf. Keyes 2010, 8). Secondly, synonymy is a sense relation that functions on the paradigmatic level, and this applies to euphemisms and dysphemisms too. Finally, if the above-mentioned identification of one of the ways in which synonyms can differ is taken into account, euphemisms and dysphemisms can indeed be regarded as a specific type of synonymic sense relation that is inextricably connected to stylistic aspects of linguistic expressions. This will become evident in subsequent parts of the paper, i.e., in the analysis of the corpus where reference is made to lexicographic notes on stylistic aspects of euphemisms.

On the other hand, the investigation of euphemisms and dysphemisms in a given sociocultural context provides the possibility to investigate these two phenomena not only from the point of view of their stylistic value and use, but also from the point of view of the social value that is attached to such expressions. Such a sociolinguistic analysis could significantly contribute to research where the only focus is placed on the typological and lexicographic classifications of euphemisms and dysphemisms. Thus, euphemisms and dysphemisms may be regarded as indicators of sociocultural changes that have occurred in a given community. Similarly, Keyes $(2010,10)$ refers to euphemisms as "an accurate barometer of changing attitudes".

Rocco $(2015,258)$ states that the term euphemism is multi-faceted, and not only can it be seen as a linguistic but also as a social phenomenon, whose stylistic-rhetoric impact was already studied in the antiquity. In contrast, the term dysphemism has not been used for such a long time, and can be linked to investigations of vulgar words, pejoratives, slurs, etc. Rocco $(2015,259)$ sees euphemisms as hyperonyms for using linguistic means with mantling, blurring, weakening, or palliative functions, whereas dysphemisms refer to language use which is pejorative, which creates distance or stigmatizes persons or ideas. Euphemisms and dysphemisms can be seen as dynamic and interactional categories, whose production and reception depend on the context and text types.

Keyes (2010) also notes the importance of euphemisms in illuminating those areas of life that a community is particularly sensitive about at different periods. Similarly and more specifically, Kuna $(2007,100-101)$ makes reference to Moskvin $(2001,62)$ in discussing communicative functions of euphemisms, one of which is to replace the items which are considered inappropriate at a given point in time or in a given community, and these have to do with "states, physiology, and human anatomy". Kuna $(2007,101)$ illustrates this function of euphemisms by several examples from Croatian, e.g., "upitna ljepota - 'ružnoća"’’.

Different functions of euphemisms become evident in comparative analyses of values of different cultures and the ways in which such values are transferred onto the linguistic arena. Namely, it has been noted that "the usage of euphemisms develops from and builds up community's beliefs as a sharing ground in that community" (Yang and Depner 2016, 95). Yang and Depner (2016) obviously place substantial emphasis on the relevance of folk beliefs in their analysis of specific euphemisms in Mandarin Chinese. A cross-cultural and

3 “Questionable beauty - 'ugliness". 
cross-linguistic analysis in which, for example, the situation in Mandarin Chinese would be compared to the situation in American English, might hypothetically reveal that in comparison to Eastern cultural and linguistic systems, in the Western ones a greater emphasis is placed on political correctness rather than specific folk beliefs in the processes of creating and using euphemisms.

\section{Euphemisms and Dysphemisms - Where Should the Line Between the Two Be Drawn?}

If euphemisms and dysphemisms are regarded as particular types of partial synonyms which are used in situations in which one expression is substituted with another, and where both refer to the same concept, we may analyse the possibilities of drawing a clear line between what may be regarded as a euphemism and what may be regarded as a dysphemism. The line between the two is in some cases blurred, and it seems that the reason behind this is rather subjective and related to users' intention or illocutionary force. Casas Gómez (2018, 16) identifies the differences between the two in "motivation and purpose", and claims that "although both euphemism and dysphemism are based on the same principle and use the same linguistic devices, the aim of dysphemism is not to attenuate or soften, but to have the opposite effect, the motivation or reinforcement of the forbidden sign or concept". Some expressions are undoubtedly euphemisms and have nothing to do with the purpose behind using an expression that might be identified as a dysphemism. However, there are certainly cases in which an expression might be classified by a lexicographer as a euphemism, but may be used as a dysphemism in different contexts. Allan and Burridge $(2006,31)$ claim that individuals use dysphemisms "to talk about people and things that frustrate and annoy them, that they disapprove of and wish to disparage, humiliate and degrade". In this sense, among the analysed euphemisms presented later on in this paper, some might be regarded as dysphemisms if they are perceived by native speakers as expressions that they might use in order to ridicule or humiliate. In distinguishing between euphemisms and dysphemisms, emphasis is also placed on the emotional or affective aspect. Thus, euphemisms are described in terms of carrying "a light emotional load", and dysphemisms in terms of carrying "a heavy affective load" (Herrero Ruiz 2009, 252).

Terminological distinctions used by scholars illustrate how difficult it is to distinguish between euphemisms and dysphemisms. Allan and Burridge (1991) discuss 'euphemistic dysphemisms' and 'dysphemistic euphemisms', and what seems to be the basic criterion for the distinction between the two is the speaker's intention, i.e., the illocutionary force of an utterance. ${ }^{4} \mathrm{Crespo}$ Fernández (2007) analyses the space between euphemisms and dysphemisms in relation to 'quasi-euphemisms' and 'quasi-dysphemisms'. 'Quasi-euphemisms' have the euphemistic illocutionary force, but dysphemistic form, while 'quasi-dysphemism' take the form of a euphemism, but have a humiliating or degrading illocutionary force (Crespo Fernández 2007, 214). Moreover, in his thorough analysis of the two phenomena Crespo Fernández

A focus on illocutionary force is evident in scholars' analysis of euphemisms in relation to saving face (cf. Allan and Burridge 1991). See also Allan and Burridge (2006) regarding the distinction between dysphemisms, orthophemisms, and euphemisms. 
(2007) investigates, among other perspectives, the ironic perspective of quasi-dysphemisms. Since the corpus consists of expressions which are attested by lexicographers as euphemisms, i.e., they appear in the form of a euphemism, we may hypothesize that some of the analysed items might be identified as quasi-dysphemisms, and their use might be closely associated with irony as illocutionary force. This becomes especially plausible if we consider the fact that in today's society different aspects of a person's physical appearance are frequently ridiculed and referred to in ironic terms (which is not the case with, for example, euphemisms related to death or religion). It is evident that scholars rely heavily on speaker meaning, i.e., the illocutionary force of an utterance in distinguishing between euphemisms and dysphemisms. However, Warren (1992) emphasizes the importance of an individual's evaluation of what is communicated by the speaker as an attempt to euphemise a certain concept. Thus, native speakers' evaluations of items classified as euphemisms provide a valuable insight into the overall value of an expression.

\section{English and German Euphemisms Related to Obesity - Corpus Analysis}

This part of the paper consists of the presentation of the methodology of the research, analysis of lexicographic presentation and semantic changes of English and German euphemisms related to obesity, as well as the analysis of native speakers' evaluations of such expressions.

\subsection{Methodology}

For the purpose of comparing the ways in which euphemisms related to obesity are dealt with in general and specialized dictionaries, the analysis of selected items ${ }^{5}$ which are included in Holder's dictionary of euphemisms (2002) will also include reference to the ways in which these items are dealt with in the online edition of Oxford English Dictionary. ${ }^{6}$ The aim of this part of the analysis is to evaluate the extent to which lexicographers identify these items as euphemisms in general dictionaries and the extent to which they simply regard them as (stylistically) marked expressions without further classification of such items as euphemisms. The importance of this type of analysis is attested by Pasini $(2005,62)$, who discusses the situation in Croatian with regard to the lexicographic identification of euphemisms and the dilemmas that lexicographers working on general dictionaries encounter in dealing with such items and indicating '(stylistically) marked words' or 'loaded words'.

Since euphemisms have previously been identified as indicators of sociocultural changes in a given community, the aim of the questionnaire is to gain insight into native speakers' evaluations of the ways in which obesity is euphemised and to relate these to lexicographers' approaches and analyses of such euphemisms. It should be noted here that Holder's dictionary of euphemisms (2002) relies on different dictionaries, reference books, and literary sources

\footnotetext{
The conducted research included euphemisms related to 'obesity' and 'cosmetics', as identified in Holder (2002). However, since the collected data for both is extensive, in this paper we present only the results related to items referring to obesity. Furthermore, the expression 'led astray' is also listed under the semantic field of obesity in Holder (2002). However, since its meaning is too broad (see Holder 2002, 230) and since it is also listed by Holder under the semantic fields of copulation and drunkenness, it is not included in this analysis.

6 https://en.oxforddictionaries.com/english. Accessed January 16, 2019.
} 
which cover a substantial period of time, some of them dating several centuries back. In that respect, the informants' feedback regarding the evaluations of items listed in Holder's dictionary provides a valuable insight into the extent to which contemporary means of euphemising obesity differ from those used in the past. The relevance of taking the temporal dimension in both the identification of linguistic expressions as euphemisms and their evaluation is attested by Burridge and Benczes $(2019,190)$ who claim the following: "In the life cycle of a euphemism, wear and tear sees metaphorical ties cut, imagery buried, and expressions stripped of their force; time pushes these expressions below the level of consciousness". The data collected via the questionnaire thus provide a valuable insight into the changes in perception and use of different linguistic items as euphemisms. This, in turn, allows for the possibility of drawing a clearer line between items that might be regarded as euphemisms and those that might be regarded as dysphemisms. Namely, if speakers use dysphemisms to discuss annoying individuals, objects or phenomena with the intention to humiliate, as indicated by Allan and Burridge (2006,31), it becomes evident why expressions related to obesity represent a productive arena for such investigations. Namely, with the development of technology and new forms of social media and ways of communicating, there has been an increase in pressure on individuals to conform to certain standards of physical appearance, but also an expansion of virtual spaces where one might be humiliated for not conforming or living up to a standard of physical beauty.

Furthermore, it is possible to draw additional conclusions from the synchronic analysis. Since Holder (2002) associates certain euphemistic expressions with a specific gender, the questionnaire elicits this type of response as well. Age and education were found to be the most important variables in the evaluations of use and understanding of other figures, such as antonomasia (cf. Grgić and Nikolić 2011, 131). However, since our sample is relatively restricted, we were not able to use these variables in establishing correlations.

\subsection{Analysis of Lexicographic Presentation and Semantic Changes of Euphemisms Related to Obesity}

This part of the paper consists of the analysis of lexicographic presentation and semantic changes of English and German euphemisms related to obesity.

\subsubsection{Analysis of English Euphemisms}

This part consists of the presentation of euphemisms related to obesity as identified and defined by Holder (2002), and a comparison with the treatment of that item in the online Oxford English Dictionary. After such a comparison, reference will also be made to semantic phenomena that might be identified within the examples.

ample fat. Literally, wide and commodious, but only in this sense of a woman ${ }^{7}\left(\mathrm{H}^{8}, 9\right)$. In one of the two indicated subsenses the general dictionary offers the following definition: (of a person's

Bolded item refers to the euphemism, followed by its meaning in Holder, which is not placed in bold. The part in italics refers to Holder's further comments about the item. Italics are also used where OED definitions are provided. H stands for Holder (2002). 
figure) full or broad (OED) ${ }^{9}$. It should be noted that Holder also includes a full figure as a euphemism, so it could be noted here that a euphemism is in OED defined with a further euphemism. There is no indication in OED that this is a euphemism.

battle of the bulge a desire to slim. The 'bulge' is the evidence of obesity around the waist and hips $(\mathrm{H}, 22)$. Here there is also reference to the Battle of the Bulge, fought during World War II. OED defines 'bulge' in the following way: a rounded swelling which distorts an otherwise flat surface, but also as: informal [in singular] an unusual temporary increase in number or size. Here there is also an indication for informality.

bay window a fat person's stomach. Literally, the architectural feature of a house which protrudes from the lower floor only $(\mathrm{H}, 22)$. In OED the following definition of the expression is given: a window built to project outwards from an outside wall. No further subsenses are provided or an indication for style.

big-boned fat. The phrase is used of children and adults, seeking to suggest that their frame needs the extra padding $(\mathrm{H}, 28)$. In OED this adjective is defined only as: (of a person or animal) of larger than average build. There is no indication for style.

brewer's goitre frontal obesity in a male. The thyroid gland, from the swelling of which you may find yourself with a 'goitre', is situated in the neck, not around the waist $(\mathrm{H}, 42)$. In OED this expression is defined as: a fat stomach caused by excessive consumption of beer, and it is marked as NZ, Australian, informal. Here it is interesting to note that Holder defines this euphemism with a further euphemism ('frontal obesity'), while OED does not.

calorie counter a fat person. Advertising jargon, suggesting that the physical condition is not due to gluttony, the lack of exercise, and so on $(\mathrm{H}, 52)$. OED does not offer this expression, but in one of its senses 'counter' is defined in the following way: a device used for counting, and in one of the subsenses: a person who counts something, for example votes in an election.

chubby fat. Literally, like the thick, coarse-fleshed fish, whence agreeably plump, especially of babies. You meet the adjective in advertisements calculated to avoid upsetting mothers who have to select capacious clothes for an obese child $(\mathrm{H}, 65)$. In $\mathrm{OED}$ it is defined as: plump and rounded. Here the euphemism is defined by further euphemisms.

classic proportions (of) fat. Originally, 'classic' meant belonging to the literature of Greek or Latin antiquity when that was considered the only stuff worth reading, less taxing literature being written in the vernacular, or Romance, whence our modern romantic novels. The female models chosen by Rubens and other old masters, or 'classic painters, were nearly always on the plump side $(\mathrm{H}, 66)$. In OED the item 'proportions' is in one subsense defined as: dimensions; size, and 'the classics' as: the works of ancient Greek and Latin writers and philosophers.

contour a fat shape. Literally, the outline of any figure, but promising to 'reduce your contour' is how advertisers try to sell you health foods, exercise equipment, and the like $(\mathrm{H}, 82)$. In OED it is defined in one sense as: an outline representing or bounding the shape or form of something.

Oxford English Dictionary. 
corn-fed American (of a female) plump. Especially referring to one below middle age, from the fattening of livestock on an augmented diet $(\mathrm{H}, 85)$. In OED in one subsense it is defined in the following way: plump; well fed. Here it is also marked as American, but also as informal.

couch potato a person who habitually spends their leisure time watching television. Not a vegetable related to the pernicious couch-grass, or 'triticum repens', but a person vegetating on a sofa $(\mathrm{H}, 86)$. In OED it is marked as informal and defined as: a person who spends little or no time exercising and a great deal of time watching television.

devoted to the table gluttonous. Not merely fond of a piece of furniture (H, 103). There is no entry for this expression in OED.

differently affected by a taboo condition. In a series of phrases such as 'differently abled', crippled or of low intelligence; 'differently advantaged', 'poor'; differently weighted, obese (H, 104-05); cf. OED definition of 'differently'.

dine well to be a drunkard and a glutton. The goodness lies in the excess of food and wine $(\mathrm{H}$, 105). There is no entry in OED, but there is OED's entry for 'well' with the subsense: to a great extent or degree (often used for emphasis).

fond of excessively addicted to. More than just being favourably disposed towards. Thus a man who is 'fond of the women' is a profligate, and he who is 'fond of a glass' drinks too much alcohol, or, if 'fond offood', is a glutton ( $\mathrm{H}, 148)$; cf. OED definition of 'fond of'.

full figure (a) obesity. Having a full figure does not imply merely that you have all normal anatomical appendages. The expression is used of women more than men. (...) A fuller figure means much the same (H, 156). In OED 'full' is in one of its senses defined as: (of a person's figure or part of the body) plump or rounded.

go to the fat farm American to be obese. Not visiting a piggery (H, 170). In OED 'fat farm' is marked as North American and informal, and defined as: a residential establishment where overweight people seek improved health by dieting, exercise, and treatment.

heavily built obese. Mainly of teenage children $(\mathrm{H}, 186)$. In OED the expression is entered as: (of a person) having a large, broad, and strong body.

larger obese. Jargon of the clothing industry, without stating the norm against which the measurement has been made. It may also refer to females who are taller than the norm (H, 226). In OED 'large' is defined in one of its senses as: of considerable or relatively great size, extent, or capacity.

many pounds heavier much fatter. Perhaps written more of women, who can be more sensitive on the subject of weight than men $(\mathrm{H}, 248)$. No entry in OED in this form and meaning.

maturer fatter. The language of those who seek to sell clothes to older women, who generally have put on weight and acquired a maturer figure ( $\mathrm{H}, 250)$. In OED there is no entry for 'maturer' in this sense. The term 'figure' in one of the senses is defined as: a person's bodily shape, especially that of a woman and when considered to be attractive. In one of the subsenses 'mature' is defined 
in the following way: used euphemistically to describe someone middle-aged or old. Here the general dictionary explicitly indicates that it is a euphemism, but not in the sense 'fat'.

middle-aged spread obesity. A normal function of ageing $(\mathrm{H}, 254)$. In OED the expression is defined as: the fat that may accumulate around the abdomen in middle age. It is not marked as a euphemism in OED.

people of/with those having a particular characteristic. POLITICALLY CORRECT language adopted by those so described. (...) People of size, which might be thought to include all of us and not just interior decorators fixing wallpaper, does not refer to stature but to girth (H, 295). In OED there is 'of a size' entry: (of two or more people or things) having the same dimensions.

problem an unwanted and often irreversible condition. The word is used in many phrases to conceal truth or inadequacy. (...) Staying with health, the obese may have a weight problem $(\mathrm{H}$, 314-315). In OED in one sense: a matter or situation regarded as unwelcome or harmful and needing to be dealt with and overcome.

puppy fat obesity in a child. Usually of a young female, with the implication that the plumpness will vanish as the child grows up, without any dietary change or regular exercise $(\mathrm{H}, 320)$. In OED it is marked as British, but there is no indication of it being a euphemism: fat on the body of a baby or child which disappears around adolescence.

quantitatively challenged fat. But not Sumo wrestlers $(\mathrm{H}, 324)$. In OED, 'challenged' is listed as: [with submodifier or in combination] used euphemistically to indicate that someone suffers disability in a specified respect, and in its subsense: informal. Used to indicate that someone or something is lacking or deficient in a specified respect. This is a rare instance of the indication of a euphemistic expression in a general dictionary, which illustrates how relevant the 'challenged' modifications are for creating English euphemisms (cf. also OED's comment on the usage of 'challenged' when modified by an adverb).

shorten the front line to lose weight. Punning on the military euphemism and usually of men. $(\mathrm{H}, 360)$. 'Front line' in OED: the military line or part of an army that is closest to the enemy.

spare tyre obesity at the waistline. Usually of a male, from the roll of fat overhanging his belt. (...) In America, sometimes as rubber tive (H, 376). In OED in the second indicated sense: $a$ roll of fat round a person's waist, marked only as informal.

stomach (a) obesity around the waist. Usually of a male and incorrectly specifying the internal chamber through which food passes in the process of digestion. A bit of a stomach also implies obesity rather than postsurgical deprivation ( $\mathrm{H}, 398)$. In OED 'a bit of a -' is defined in the following way: used to suggest that something is not severe or extreme, or is the case only to a limited extent.

tuck the cosmetic removal of surplus fat or flesh by surgery. The imagery is from adjusting clothing, whence also to 'tuck', to perform such a procedure $(\mathrm{H}, 415)$. In OED in one of its senses: a flattened, stitched fold in a garment or material, typically one of several parallel folds put in a garment for shortening, tightening, or decoration. In a subsense it is marked as informal and usually with modifier: a surgical operation to reduce surplus flesh or fat. 
weight watcher an obese person. But at least conscious of it and often trying to do something about it $(\mathrm{H}, 435)$. Unlike calorie counter, this expression is entered in OED as: a person who is concerned about their weight, especially one who diets. In OED there is the indication of origin: from the proprietary name Weight Watchers, an organization for slimmers.

well-built fat. Used of men and women, and of children also, because manufacturers know better than to describe somebody's little darling as obese. Less often as well-fleshed (H, 435). 'Well-built' in OED: (of a person) having a strong, sturdy physique. Here the meaning does not imply 'fat', and there is no indication of it being a euphemism. 'Well-fleshed' in OED: having a substantial amount of flesh; plump, fleshy, well-covered. Here there is no indication of the term being a euphemism, but it is defined by further euphemisms.

Our analysis of expressions related to obesity and entered in the dictionary of euphemisms and in the general dictionary points to several conclusions. Firstly, it may be observed that most expressions are not marked as euphemistic in the general dictionary. Exceptions to this are the items 'challenged' and 'mature' (although the euphemistic sense of 'mature' is related to age, and not obesity). Secondly, instead of indicating certain expressions as euphemistic, there is in certain instances an indication of style, and such expressions are marked as informal ('bulge', 'brewer's goitre', 'corn-fed', 'couch potato', 'fat farm', 'challenged', 'spare tyre', 'tuck'). Furthermore, there are also instances where, instead of indicating an expression as euphemistic, it is defined by further euphemisms ('ample', 'chubby', 'well fleshed'). Lastly, there seems to be no indication of certain expressions obviously being derogatory, such as 'corn-fed', 'couch potato', or '(go to) the fat farm'.

What may also be noted from the semantic point of view is that these examples include some of the semantic phenomena identified by different authors as prominent in the creation of euphemisms. ${ }^{10}$ Sometimes more than one phenomenon can be identified within a single expression. We find the frequent use of metaphor (e.g., 'battle of the bulge', 'bay window', 'couch potato', 'puppy fat', 'spare tyre'), metonymy (e.g., 'battle of the bulge, 'big-boned', 'brewer's goitre', 'devoted to the table'), and periphrasis (e.g., 'devoted to the table', 'go to the fat farm', 'many pounds heavier', 'middle-aged spread', 'shorten the front line').

\subsubsection{Analysis of German Euphemisms}

German examples are found in Duden online ${ }^{11}$ and DWDS ${ }^{12}$. They are also looked up in the dictionary "Sag es treffender" by A.M. Textor (2002), which contains synonyms. There is no dictionary of the German language which deals solely with euphemisms. Most of the following explanations also contain examples of usage of euphemisms.

dick (fat; of considerable, more than normal extent; massive, bulky, not thin): von beträchtlichem, mehr als normalem Umfang; massig, nicht dünn $n^{13}$ (e.g. ein dickes Kind, sie hat dicke Beine, du bist dick geworden, das Kleid macht dich dick; (umgangspprachlich) das Baby

\footnotetext{
See the previous part of the paper where this is presented.

https://www.duden.de. Accessed January 29, 2019.

Digitales Wörterbuch der deutschen Sprache; https://www.dwds.de. Accessed January 29, 2019.

Italics refer to the definitions found in dictionaries.
} 
ist dick und rund; (umgangssprachlich) er ist dick und fett) (Duden). Duden online gives many synonyms which refer to obesity (like 'dicklich', 'gallertartig', 'klumpig', 'aufgeschwollen', 'rund', 'rundlich', 'fett', 'fettleibig', 'wohlbeleibt', 'pummelig', 'kugelrund', 'üppig'), but also to other related senses.

dicklich (fattish, chubby; tending to abundance, a bit fat): zur Fülle neigend, etwas dick (ein dickliches Kind, Gesicht; er ist in der letzten Zeit etwas dicklich geworden) (Duden)

fett (fatty, adipose; very fat, endowed with fat tissue): sehr dick, mit viel Fettgewebe ausgestattet (e.g. ein fetter (abwertend; sehr beleibter, korpulenter) Mann, fett sein, werden) (Duden)

massig (massive, bulky; to give the impression of oppressive weight based on size and dimension; slang: plentiful, very much): aufgrund der Größe, des ausladenden Umfangs den Eindruck von lastendem Gewicht vermittelnd; wuchtig (eine massige Gestalt) (Duden); salopp: massenhaft, sehr viel (er trinkt/isst massig) (DWDS)

mollig (plump, chubby; especially for women: a round figure): (besonders von Frauen) weiche, runde Körperformen aufweisend, rundlich vollschlank (e.g. ein molliger Typ; sie ist mollig (verhüllend; dick) geworden; (substantiviert:) Kleider für Mollige (mollige Frauen) (Duden); umgangssprachlich: rundlich, vollschlank (eine mollige Dame, ein molliger Säugling, das Mädchen hat eine mollige Figur, das Baby hat mollige Händchen, bequeme, passende Kleidung für die Molligen) (DWDS)

üppig (ample; rounded forms): rundliche, volle Formen zeigend (ein üppiger Busen) (Duden)

Couch-Potato (not sporty but sitting on the couch): jemand, der sich nicht sportlich betätigt, sondern vorwiegend [fernsehend] auf der Couch sitzt oder liegt (Duden)

Futter: gut im Futter sein/stehen (literally: be/stay good in feed; colloquial: well nurtured) (umgangssprachlich: gut genährt sein) (Duden)

grobknochig (big-boned; to show strong bone structure): einen starken, kräftigen Knochenbau aufweisend (eine grobknochige Gestalt) (Duden)

kugelrund (tubby; well-fed and fat; humorous: very fat): wohlgenährt und entsprechend dick [als Ausdruck bester Gesundheit] (scherzhaft, ein kugelrundes Baby) (Duden); scherzhaft, bildlich: sehr dick (DWDS)

pummelig (lumpy, chubby; colloquial rounded, fatty): umgangssprachlich, rundlich, dicklich (ein pummeliges Kind) (Duden)

vollschlank (stout, plump; euphemistic for women: rounded, corpulent): verhüllend, (besonders von Frauen) füllig, rundlich (eine vollschlanke Frau, Figur) (Duden); ein wenig füllig, rundlich, besonders von Frauen (eine vollschlanke junge Frau, dieses Kleid, Modell eignet sich besonders für Vollschlanke) (DWDS)

esslustig (gluttonous): Esslust habend (Duden) 
rundlich (rounded; a bit fat, plump): ein wenig dick, füllig, mollig (eine rundliche Blondine; rundliche Formen haben; er ist in letzter Zeit etwas rundlich geworden) (Duden)

wohlbeleibt (stout, corpulent): ein untersetzter wohlbeleibter Mann, eine wohlbeleibte ältere Dame, er war wohlbeleibt (DWDS)

wohlgenährt (well-fed): ein wohlgenährtes Baby; jmd. ist wohlgenährt, sieht wohlgenährt aus (DWDS)

der Babyspeck (baby fat; colloquial humorous: rounded forms like in babies or small children): umgangssprachlich scherzhaft, rundliche Formen, die der Körper eines Säuglings oder Kleinkindes aufweist; Fettpolster als (meist unerwünschte) rundliche Körperformen eines Teenagers (Duden)

der Schmerbauch (potbelly; colloquial derogatory, also humorous): umgangssprachlich abwertend, auch scherzhaft; dicker, vorgewölbter Bauch mit starkem Fettansatz (einen Schmerbauch haben); jemand, der einen Schmerbauch hat (wer ist denn der Schmerbauch da drüben?) (Duden)

The presented words are not described as euphemisms or dysphemisms, only the words 'mollig' and 'vollschlank' are marked as verhüllend (euphemistic), and 'kuglerund' as scherzhaft (humoristic). Some others are marked as umgangssprachlich (colloquial): 'pummelig', 'gut im Futter sein', 'Babyspeck', 'Schmerbauch'. 'Fett' is marked as abwertend (derogatory) only in the context ein fetter Mann (a fat man). Beside these senses, 'dick' also means thick, dense, close, familiar, very; 'dicklich' means viscous, thick; 'massig' also means plentiful. 'Pummelig' and 'kugelrund' are used for chubby children, 'vollschlank' and 'mollig' for women, 'üppig' for big breasts.

As in the English corpus, metaphor is found in 'Couch-Potato', periphrasis in 'Babyspeck', 'Schmerbauch', and metonymy in 'grobknochig'.

The dictionary "Sag es treffender" (2002: 45) gives synonyms for 'dick' (fat), without giving any other information about the usage and stylistic value of these lexemes. Possible ways of referring to a fat person are simply listed as follows: 1. stark, korpulent, stattlich, massiv, beleibt, wohlbeleibt, schmerbäuchig, rund, rundlich, dicklich, mollig, pummelig, wohlgerundet, füllig, vollschlank, gut gepolstert, stramm, drall, üppig, fett, feist, gut im Futter, fleischig, bullig, wohlgenährt, fettleibig, dickleibig, kugelrund, gemästet, prall, gewaltig, unförmig, übergewichtig, voll gefressen, 2. angeschwollen, aufgedunsen, aufgeblasen, aufgetrieben, aufgenäht, schwammig, aufgeschwemmt, 3. geschwollen, entzündet, wund, verdickt, 4. schwellend, wulstig, aufgeworfen, gerundet, bauchig, vorgewölbt, gewölbt, herausstehend, vorstehend, überstehend, vorspringend, vorkragend, ausladend, kugelig.

\subsection{Native Speakers' Evaluations of Euphemisms Related to Obesity}

This part of the paper consists of the presentation and analysis of the results of the second part of the research investigating native speakers' evaluations of English and German euphemisms related to obesity. 


\subsubsection{Native Speakers' Evaluations of English Euphemisms}

For the purpose of investigating native speakers' evaluations of euphemisms related to obesity, ${ }^{14}$ a questionnaire in Google Forms was offered to native English speakers from the United States. The research was conducted from December 2018 to March 2019 among nineteen participants. The participants were aged eighteen to fifty-six, and just over half (ten of nineteen) were in their twenties. Seventeen participants were female, and only two were male.

The participants were asked the following question: "How sensitive is American society towards issues related to physical appearance in the sense that attention is paid to what sort of language is used to refer to individuals and situations related to aspects of physical appearance (obesity, cosmetic procedures, etc.)?”. Only one participant stated that American society was not sensitive to such issues. Some claimed that it was either moderately/fairly/in part sensitive, and others stated that it was highly/extremely/very sensitive. One stated that it depended on the person, and another participant claimed that it depended on both person and context. Here are some of their responses:

Americans in my experience are generally politically correct. Meaning they are very careful for the most part of how we address someone's looks or general appearance. People are generally sensitive and do not address how someone looks unless you are telling them something positive. Online however is another matter altogether. People will say anything online. (P3)

I feel like we are generally pretty sensitive, at least when we are around others who don't fit the stereotypically 'beautiful' categories. However, our media portrayals, comedians, and comments online are not so sensitive. (P5)

As a whole, usually negative language is used to describe people who deviate from societal norms physically. In my experience, Americans can be quick to jump to character judgement based on physical appearance, (i.e., if you are obese you are lazy, [if you have] cosmetic procedures you're vapid) (P10)

P3's and P5's responses are interesting as they point to the previously mentioned issue that has to do with the increase in interaction via different forms of social media, and the fact that this opens up new possibilities for using different linguistic expressions to humiliate others on the basis of their physical appearance.

In the continuation of the survey the participants were asked to identify expressions they would use to describe a person in order to avoid the use of the following offensive terms: 'fat', 'ugly', 'short', 'old', and 'bold'. ${ }^{15}$ The participants provided the following as alternatives to the offensive term 'fat': ${ }^{16}$ husky, large-boned; thicc; bigger; obese; very healthy; overweight; big, solid, big-boned, a big girl or boy, hefty; overweight, obese, bigger, larger, solid; heavy-

\footnotetext{
14 The questionnaire also included parts that refer to euphemisms that are in Holder (2002) classified under 'cosmetics'. However, as is the case with the first part of the analysis, we will only analyze the collected data related to obesity because of the length of the paper.

15 Only the participants' feedback for 'fat' will be presented here, as explained in the previous note.

16 Participants' answers are separated by semicolons.
} 
set, heavy, large; larger, bigger, fuller; walk as loud as an elephant; larger, not thin; bigger - kind of a bigger guy or larger; she has a particular body shape/body type, sort-of plump, kind-of large, s/he struggles with weight; large, heavy-set; large, overweight, big; thicc; large, heavy; overweight, large, big. Here we can note that there are certain items that appear more frequently in the participants' responses, and these are 'big(ger)', 'large(r)', and 'overweight'. The expression 'thicc' cannot be found in OED. However, an online search revealed that it is indicated in the Urban Dictionary, and defined by 'That0neguy23' in the following way: "when a person has fat in the right places, creating sexy curves" 17 .

The following part of the questionnaire consists of the list of euphemisms from Holder's dictionary. The participants were asked to evaluate the extent to which they would use each euphemism to refer to a particular concept. They were asked to do so by using a 5-point Likert scale (1-strongly disagree; 2-disagree; 3-neither agree or disagree; 4-agree; 5-strongly agree). In terms of obesity, this refers to the extent to which they would use each euphemism in order to avoid saying that a person is fat, has a fat shape, has a fat stomach (front part of the body), has (a desire) to slim or lose weight. In the last part of the survey the participants were asked to evaluate whether the items were applicable to males, females, or equally to both genders. The results are presented in Table $1 .{ }^{18}$

TABLE 1. Participants' evaluations of the extent to which they would use the selected items in the English language to euphemise a particular concept and their evaluations regarding whether the items were applicable to males, females, or equally to both genders.

\begin{tabular}{|l|c|c|c|c|c|c|c|c|c|}
\hline & 1 & 2 & 3 & 4 & 5 & M & F & M\&F \\
\hline FAT & $31.6 \%$ & $21.1 \%$ & $31.6 \%$ & $0 \%$ & $15.8 \%$ & $5.3 \%$ & $10.5 \%$ & $84.2 \%$ \\
\hline obese & $26.3 \%$ & $26.3 \%$ & $31.6 \%$ & $10.5 \%$ & $5.3 \%$ & $0 \%$ & $57.9 \%$ & $42.1 \%$ \\
\hline ample & $10.5 \%$ & $36.8 \%$ & $10.5 \%$ & $26.3 \%$ & $15.8 \%$ & $31.6 \%$ & $63.2 \%$ & $5.3 \%$ \\
\hline big-boned & $31.6 \%$ & $15.8 \%$ & $21.1 \%$ & $15.8 \%$ & $15.8 \%$ & $26.3 \%$ & $5.3 \%$ & $68.4 \%$ \\
\hline chubby & $52.6 \%$ & $15.8 \%$ & $26.3 \%$ & $5.3 \%$ & $0 \%$ & $0 \%$ & $73.7 \%$ & $26.3 \%$ \\
\hline calorie counter & $57.9 \%$ & $15.8 \%$ & $21.1 \%$ & $5.3 \%$ & $0 \%$ & $0 \%$ & $73.7 \%$ & $26.3 \%$ \\
\hline $\begin{array}{l}\text { weight watcher } \\
\text { (of) classic } \\
\text { proportions }\end{array}$ & $31.6 \%$ & $26.3 \%$ & $26.3 \%$ & $10.5 \%$ & $5.3 \%$ & $15.8 \%$ & $52.6 \%$ & $31.6 \%$ \\
\hline corn-fed & $73.7 \%$ & $15.8 \%$ & $5.3 \%$ & $5.3 \%$ & $0 \%$ & $52.6 \%$ & $0 \%$ & $47.4 \%$ \\
\hline couch potato & $42.1 \%$ & $15.8 \%$ & $31.6 \%$ & $10.5 \%$ & $0 \%$ & $57.9 \%$ & $0 \%$ & $42.1 \%$ \\
\hline $\begin{array}{l}\text { devoted to the } \\
\text { table }\end{array}$ & $57.9 \%$ & $42.1 \%$ & $0 \%$ & $0 \%$ & $0 \%$ & $42.1 \%$ & $0 \%$ & $57.9 \%$ \\
\hline $\begin{array}{l}\text { differently } \\
\text { weighted }\end{array}$ & $52.6 \%$ & $26.3 \%$ & $5.3 \%$ & $10.5 \%$ & $5.3 \%$ & $0 \%$ & $21.1 \%$ & $78.9 \%$ \\
\hline dine well & $42.1 \%$ & $26.3 \%$ & $21.1 \%$ & $10.5 \%$ & $0 \%$ & $10.5 \%$ & $10.5 \%$ & $78.9 \%$ \\
\hline
\end{tabular}

17 That0neguy23. August 30,2017 . Thicc. Urban Dictionary. https://www.urbandictionary.com/define. php?term=Thicc. Accessed May 23, 2019.

18 The percentages presented in the table were computer-generated, and the results were rounded to two decimal places. That is why the total percentage may in some cases vary from $100 \%$ by $0.1 \%(99.9 \%$ or $100.1 \%)$. 


\begin{tabular}{|c|c|c|c|c|c|c|c|c|}
\hline & 1 & 2 & 3 & 4 & 5 & $\mathrm{M}$ & $\mathrm{F}$ & $\mathrm{M} \& \mathrm{~F}$ \\
\hline fond of food & $42.1 \%$ & $26.3 \%$ & $26.3 \%$ & $5.3 \%$ & $0 \%$ & $10.5 \%$ & $10.5 \%$ & $78.9 \%$ \\
\hline $\begin{array}{l}\text { have a full(er) } \\
\text { figure }\end{array}$ & $0 \%$ & $10.5 \%$ & $15.8 \%$ & $47.4 \%$ & $26.3 \%$ & $0 \%$ & $84.2 \%$ & $15.8 \%$ \\
\hline $\begin{array}{l}\text { go to the fat } \\
\text { farm }\end{array}$ & $73.7 \%$ & $21.1 \%$ & $0 \%$ & $5.3 \%$ & $0 \%$ & $26.3 \%$ & $15.8 \%$ & $57.9 \%$ \\
\hline heavily built & $10.5 \%$ & $10.5 \%$ & $21.1 \%$ & $52.6 \%$ & $5.3 \%$ & $68.4 \%$ & $5.3 \%$ & $26.3 \%$ \\
\hline larger & $0 \%$ & $10.5 \%$ & $15.8 \%$ & $52.6 \%$ & $21.1 \%$ & $15.8 \%$ & $10.5 \%$ & $73.7 \%$ \\
\hline $\begin{array}{l}\text { many pounds } \\
\text { heavier }\end{array}$ & $42.1 \%$ & $31.6 \%$ & $26.3 \%$ & $0 \%$ & $0 \%$ & $5.3 \%$ & $0 \%$ & $94.7 \%$ \\
\hline maturer & $42.1 \%$ & $15.8 \%$ & $15.8 \%$ & $26.3 \%$ & $0 \%$ & $0 \%$ & $15.8 \%$ & $84.2 \%$ \\
\hline (be) of size & $36.8 \%$ & $36.8 \%$ & $5.3 \%$ & $21.1 \%$ & $0 \%$ & $0 \%$ & 15.8 & $84.2 \%$ \\
\hline $\begin{array}{l}\text { quantitatively } \\
\text { challenged }\end{array}$ & $57.9 \%$ & $36.8 \%$ & $5.3 \%$ & $0 \%$ & $0 \%$ & $0 \%$ & $5.3 \%$ & $94.7 \%$ \\
\hline $\begin{array}{l}\text { (have) a weight } \\
\text { problem }\end{array}$ & $31.6 \%$ & $31.6 \%$ & $21.1 \%$ & $5.3 \%$ & $10.5 \%$ & $0 \%$ & $5.3 \%$ & $94.7 \%$ \\
\hline well built & $15.8 \%$ & $5.3 \%$ & $36.8 \%$ & $36.8 \%$ & $5.3 \%$ & $26.3 \%$ & $10.5 \%$ & $63.2 \%$ \\
\hline \multicolumn{9}{|c|}{ HAVING A FAT SHAPE } \\
\hline contour & $42.1 \%$ & $21.1 \%$ & $21.1 \%$ & $10.5 \%$ & $5.3 \%$ & $0 \%$ & $57.9 \%$ & $42.1 \%$ \\
\hline maturer figure & $52.6 \%$ & $10.5 \%$ & $21.1 \%$ & $15.8 \%$ & $0 \%$ & $5.3 \%$ & $47.4 \%$ & $47.4 \%$ \\
\hline $\begin{array}{l}\text { middle-aged } \\
\text { spread }\end{array}$ & $63.2 \%$ & $21.1 \%$ & $10.5 \%$ & $0 \%$ & $5.3 \%$ & $31.6 \%$ & $0 \%$ & $68.4 \%$ \\
\hline puppy fat & $68.4 \%$ & $26.3 \%$ & $5.3 \%$ & $0 \%$ & $0 \%$ & $21.1 \%$ & $10.5 \%$ & $68.4 \%$ \\
\hline \multicolumn{9}{|c|}{ HAVING A FAT STOMACH } \\
\hline bay window & $78.9 \%$ & $21.1 \%$ & $0 \%$ & $0 \%$ & $0 \%$ & $21.1 \%$ & $5.3 \%$ & $73.7 \%$ \\
\hline $\begin{array}{l}\text { (a) bit of (a) } \\
\text { stomach }\end{array}$ & $0 \%$ & $31.6 \%$ & $36.8 \%$ & $21.1 \%$ & $10.5 \%$ & $15.8 \%$ & $15.8 \%$ & $68.4 \%$ \\
\hline brewer's goitre & $78.9 \%$ & $21.1 \%$ & $0 \%$ & $0 \%$ & $0 \%$ & $63.2 \%$ & $0 \%$ & $36.8 \%$ \\
\hline $\begin{array}{l}\text { spare/rubber } \\
\text { tyre }\end{array}$ & $47.4 \%$ & $31.6 \%$ & $15.8 \%$ & $0 \%$ & $5.3 \%$ & $52.6 \%$ & $0 \%$ & $47.4 \%$ \\
\hline \multicolumn{9}{|c|}{ HAVING (A DESIRE) TO SLIM OR LOSE WEIGHT } \\
\hline $\begin{array}{l}\text { battle of the } \\
\text { bulge }\end{array}$ & $57.9 \%$ & $31.6 \%$ & $5.3 \%$ & $5.3 \%$ & $0 \%$ & $31.6 \%$ & $10.5 \%$ & $57.9 \%$ \\
\hline $\begin{array}{l}\text { shorten the } \\
\text { front line }\end{array}$ & $68.4 \%$ & $15.8 \%$ & $5.3 \%$ & $10.5 \%$ & $0 \%$ & $15.8 \%$ & $15.8 \%$ & $68.4 \%$ \\
\hline
\end{tabular}

What can be observed on the basis of the collected data is that the following are among the expressions that the participants would use most often to replace the offensive term 'fat': 'have a full(er) figure', 'larger', and 'heavily built'. More importantly, many other expressions would not be used by the participants to replace the offensive term, which would suggest that they do not recognize them as euphemisms, but rather as dysphemisms. These include the following: 'quantitatively challenged', 'go to the fat farm', 'devoted to the table', 'fond of 
food', 'corn-fed', 'couch potato', 'calorie counter', 'weight watcher', 'differently weighted', and 'many pounds heavier'. The same can be observed for most expressions suggested to replace the offensive 'to have a fat shape', but also for those suggested to replace 'to have a fat stomach', especially 'brewer's goitre' and 'spare/rubber tyre'. Among these, '(a) bit of (a) stomach' was identified as the most acceptable euphemistic replacement for the concept. The two items classified as euphemisms for 'having (a desire) to slim or lose weight' - 'battle of the bulge' and 'shorten the front line' - were also not evaluated by the participants as expressions they would use to replace this concept.

In terms of evaluating the extent to which the participants would apply each item to the two genders, it can be observed that some items were more closely associated with the female gender (such as 'ample', big-boned', 'calorie counter', 'weight watcher', 'of classic proportions', 'have a full(er) figure', 'contour', 'maturer'), while others were more closely associated with the male gender (such as 'corn-fed', 'couch potato', 'devoted to the table', 'heavily built', 'brewer's goitre', spare/rubber tyre', 'amply endowed'). In comparison to Holder's entries for these items, it can be observed that there are both similarities and differences in lexicographic and native speakers' association of expressions with the two genders. For example, 'ample' and 'full(er) figure' are in Holder (2002) associated primarily with the female gender, and none of the participants associated these items with the male gender. Similarly, 'brewer's goitre' and 'spare/rubber tyre' are in Holder (2002) associated with the male gender, and none of the participants associated these items with the female gender. On the other hand, none of the participants associated the expressions 'calorie counter' and 'weight watcher' with the male gender either, but these items are not associated with either gender in Holder (2002). Furthermore, in Holder (2002) 'corn-fed' is associated with the female gender, while none of the participants associated the expression with the female gender.

In their elaboration of dysphemisms, Keith Allan and Kate Burridge (2006) claim that such expressions are frequently used in the political arena and in different situations of cross-gender reference, and state that they "include curses, name-calling, and any sort of derogatory comment directed towards others in order to insult or to wound them" (31). The analysed euphemisms do not belong to the category of curses or name-calling, nor are they characteristically used in the political arena. However, since the analysed items refer to aspects of physical appearance, some of them are more gender-specific in terms of the referent, which is what the results of this part of the analysis point to.

\subsubsection{Native Speakers' Evaluations of German Euphemisms}

In the group of native speakers of the German language, the participants are divided into 10 from Austria (seven female, three male) and 10 from Germany (five female, five male). The participants described both societies as "very/extremely/highly sensitive, very careful about the way obese people are referred to, especially in their presence". If words are understood as derogatory, that depends on the relationship and stance among the partners in communication.

The German list of euphemisms was compiled from Duden online, DWDS and Textor's (2002) dictionary of synonyms. In the first part of the questionnaire, the participants were 
asked to name the words they would use to avoid calling/referring to someone as 'fett'. They stated the following: stärker, korpulent, rundlich; kräftig, gut gebaut, pummelig, rund, kugelig; korpulent, übergewichtig; mollig, rund, untersetzt, dick; barock, füllig, moppelig; mollig, schwere Knochen, breit, pawg, thic, speckig, schwer, optimierungsfähig, voluminös; beleibt, mollig, kräftig; stattlich, korpulent, barock, adipös, übergewichtig; korpulent, adipös; mollig, korpulent, gut genährt; stärker, dicklich; fest, füllig, dick; korpulent, stämmig, mollig; wohlbeleibt, korpulent, gut genährt; korpulent, füllig, rundlich, so breit wie hoch, hat viel Hüftgold, eine Wuchtel; stark/gut gebaut, stämmig, massig, rundlich, übergewichtig, blad, korpulent, starke Knochen; dick, gut gebaut, starke Knochen; korpulent, wohlgenährt, stämmig; beleibt; korpulent, kräftig, vollschlank.

As in the English questionnaire, the participants were asked to evaluate the extent to which they would use each euphemism to refer to a particular concept, and the results are presented in Table 2.

TABLE 2. Participants' evaluations of the extent to which they would use the selected items in the German language to euphemise a particular concept and their evaluations regarding whether the items were applicable to males, females, or equally to both genders.

\begin{tabular}{|c|c|c|c|c|c|c|c|c|c|c|}
\hline & 1 & 2 & 3 & 4 & 5 & M & $\mathrm{F}$ & $M \& F$ & $\begin{array}{c}\text { Not } \\
\text { familiar }\end{array}$ & \begin{tabular}{|c|} 
For chil- \\
dren
\end{tabular} \\
\hline \multicolumn{11}{|l|}{ FAT } \\
\hline etwas üppig & $35 \%$ & $10 \%$ & $20 \%$ & $15 \%$ & $5 \%$ & 0 & $45 \%$ & $45 \%$ & & \\
\hline grobknochig & & & $10 \%$ & $20 \%$ & $60 \%$ & $10 \%$ & $20 \%$ & $40 \%$ & & \\
\hline pausbackig & & $5 \%$ & $15 \%$ & $30 \%$ & $40 \%$ & $10 \%$ & $20 \%$ & $50 \%$ & & \\
\hline mollig & $40 \%$ & $30 \%$ & $10 \%$ & $5 \%$ & $25 \%$ & 0 & $65 \%$ & $30 \%$ & & \\
\hline wohlgenährt & $40 \%$ & $20 \%$ & $5 \%$ & $15 \%$ & $10 \%$ & $15 \%$ & 0 & $70 \%$ & & \\
\hline korpulent & $55 \%$ & $20 \%$ & $5 \%$ & $5 \%$ & $5 \%$ & $10 \%$ & $5 \%$ & $75 \%$ & & \\
\hline kugelrund & $5 \%$ & 0 & $10 \%$ & $30 \%$ & $45 \%$ & $5 \%$ & 0 & $75 \%$ & & \\
\hline $\begin{array}{l}\text { Couch } \\
\text { Kartoffel }\end{array}$ & 0 & $5 \%$ & 0 & $25 \%$ & $65 \%$ & $5 \%$ & 0 & $50 \%$ & $5 \%$ & \\
\hline vollschlank & $20 \%$ & $30 \%$ & $10 \%$ & $10 \%$ & $20 \%$ & 0 & $30 \%$ & $50 \%$ & $5 \%$ & \\
\hline gut im Futter & 0 & 0 & $25 \%$ & $15 \%$ & $50 \%$ & $15 \%$ & 0 & $50 \%$ & & \\
\hline stark gebaut & $25 \%$ & $20 \%$ & $35 \%$ & 0 & $30 \%$ & $20 \%$ & 0 & $55 \%$ & & \\
\hline esslustig & 0 & 0 & 0 & $10 \%$ & $85 \%$ & 0 & $5 \%$ & $55 \%$ & $5 \%$ & \\
\hline pummelig & $15 \%$ & $40 \%$ & $15 \%$ & $15 \%$ & $10 \%$ & 0 & $25 \%$ & $65 \%$ & & $25 \%$ \\
\hline rundlich & $25 \%$ & $35 \%$ & $20 \%$ & $10 \%$ & 0 & 0 & $25 \%$ & $65 \%$ & & \\
\hline dicklich & $10 \%$ & $25 \%$ & $15 \%$ & $20 \%$ & $20 \%$ & $5 \%$ & $5 \%$ & $60 \%$ & & \\
\hline ausgeleiert & 0 & 0 & 0 & 0 & $85 \%$ & 0 & $10 \%$ & $50 \%$ & $5 \%$ & \\
\hline gut gepolstert & 0 & $15 \%$ & $40 \%$ & $15 \%$ & $20 \%$ & 0 & $5 \%$ & $80 \%$ & & \\
\hline massig & $10 \%$ & $20 \%$ & $10 \%$ & $25 \%$ & $25 \%$ & $45 \%$ & $5 \%$ & $30 \%$ & $5 \%$ & \\
\hline drall & $5 \%$ & $5 \%$ & $5 \%$ & $20 \%$ & $55 \%$ & 0 & $45 \%$ & $15 \%$ & $10 \%$ & \\
\hline
\end{tabular}




\begin{tabular}{|c|c|c|c|c|c|c|c|c|c|c|}
\hline & 1 & 2 & 3 & 4 & 5 & M & $\mathrm{F}$ & $M \& F$ & $\begin{array}{c}\text { Not } \\
\text { familiar }\end{array}$ & \begin{tabular}{|c|} 
For chil- \\
dren
\end{tabular} \\
\hline \multicolumn{11}{|c|}{ HAVING A FAT SHAPE } \\
\hline $\begin{array}{l}\text { ein Gewicht- } \\
\text { sproblem } \\
\text { haben }\end{array}$ & $15 \%$ & $15 \%$ & $15 \%$ & $10 \%$ & $25 \%$ & 0 & 0 & $85 \%$ & & \\
\hline Brocken & $15 \%$ & $5 \%$ & $15 \%$ & 0 & $50 \%$ & $30 \%$ & 0 & $30 \%$ & & \\
\hline \begin{tabular}{|l} 
abgerundete \\
Figur \\
\end{tabular} & 0 & 0 & $5 \%$ & $5 \%$ & $85 \%$ & 0 & $5 \%$ & $60 \%$ & & \\
\hline \multicolumn{11}{|c|}{ HAVING A FAT STOMACH } \\
\hline Babyspeck & 0 & $25 \%$ & $15 \%$ & $10 \%$ & $40 \%$ & 0 & $10 \%$ & $60 \%$ & & \\
\hline \begin{tabular}{|l|}
$\begin{array}{l}\text { Schwimm- } \\
\text { reifen }\end{array}$ \\
\end{tabular} & $15 \%$ & $10 \%$ & $15 \%$ & $25 \%$ & $25 \%$ & $25 \%$ & $5 \%$ & $50 \%$ & & \\
\hline $\begin{array}{l}\text { Wohlstands- } \\
\text { bauch }\end{array}$ & $10 \%$ & $20 \%$ & $20 \%$ & $5 \%$ & $35 \%$ & $55 \%$ & 0 & $15 \%$ & & \\
\hline Schmerbauch & $5 \%$ & 0 & 0 & $5 \%$ & $75 \%$ & $15 \%$ & 0 & $35 \%$ & $10 \%$ & \\
\hline \multicolumn{11}{|c|}{ HAVING (A DESIRE) TO SLIM OR LOSE WEIGHT } \\
\hline $\begin{array}{l}\text { immer weniger } \\
\text { werden }\end{array}$ & 0 & $20 \%$ & $15 \%$ & $10 \%$ & $40 \%$ & $5 \%$ & 0 & $65 \%$ & & \\
\hline $\begin{array}{l}\text { vom Fleisch } \\
\text { fallen }\end{array}$ & $25 \%$ & $15 \%$ & $10 \%$ & $15 \%$ & $20 \%$ & 0 & $5 \%$ & $70 \%$ & & \\
\hline sich verringern & 0 & 0 & $10 \%$ & 0 & $75 \%$ & 0 & 0 & $45 \%$ & $5 \%$ & \\
\hline
\end{tabular}

The table shows that over 55\% of the participants would not use 'grobknochig', 'Couch Kartoffel', 'esslustig', 'Brocken', 'Schmerbauch', 'ausgeleiert', 'abgerundete Figur' and 'sich verringern' as euphemisms for 'fat'. They would only use 'korpulent' (55\%). According to the results, $45 \%$ of the participants use 'üppig' and $60 \%$ 'mollig' for women. For both men and women, the following expressions can be used, although they are not evaluated as euphemisms: 'pausbackig', 'wohlgenährt', 'korpulent', 'kugelrund', 'vollschlank', 'gut im Futter', 'stark gebaut', 'esslustig', 'pummelig', 'rundlich', 'dicklich' and 'gut gepolstert'.

A few participants gave comments on the following expressions by describing them as derogatory or negative: 'etwas üppig', 'Couch Kartoffel', 'gut im Futter', 'esslustig', 'dicklich', 'ausgeleiert', 'massig', 'drall', 'grobknochig', 'wohlgenährt', 'kugelrund', 'Babyspeck' and 'Schmerbauch'. The following items were identified as friendly: 'pummelig', 'rundlich', 'mollig', 'gut gepolstert'. Most participants do not consider 'vom Fleisch fallen', 'gut gepolstert', 'korpulent' and 'kugelrund' as euphemisms.

What needs to be taken into consideration in the analysis of native speakers' evaluations of English and German euphemisms is the fact that the number of persons who were willing to participate in the research was relatively small. However, as the analysis of the collected data presented above suggests, native speakers' feedback is extremely important in distinguishing between euphemisms and dysphemisms. 


\section{Conclusion}

The existence of partial synonyms allows for different types of analyses whose aim is to account for the ways in which such synonyms differ and the factors that govern such differences. Adequate identification of the illocutionary force of an utterance is necessary in order to fully understand the meaning that is being communicated by the use of a linguistic expression. The importance of the speaker's intention is quite evident in certain instances of choosing one partial synonym over another, and even more so when such partial synonyms might be identified as euphemisms or dysphemisms. The analysis of euphemisms is especially relevant as it provides an insight into a specific sociocultural context at a given time, i.e., into those areas of life that are considered especially sensitive in a given context. Linguistic expressions used to refer to aspects of physical appearance, such as those referring to obesity, are, unlike some other types of euphemisms, especially conducive to the creation of both euphemisms and dysphemisms. This is particularly evident in most Western societies, in which there has been an increasing pressure to adhere to certain beauty standards.

The first part of the research points to differences in the treatment of different linguistic expressions related to obesity. Most items labelled as euphemisms in the specialized dictionary of English euphemisms are not identified as such in the general dictionary, and, if there is any special indication, such expressions are marked as informal. What has also been noted is that some euphemisms are explained by further euphemisms. In the case of linguistic expressions that resemble dysphemisms more than euphemisms, the general dictionary does not indicate them as derogatory. What has also been identified are the typical semantic phenomena that might be identified within such expressions.

The investigated German dictionaries do not mark the words as euphemisms, except for the words 'vollschlank' and 'mollig'. Most of the investigated words are marked as colloquial. Dictionaries list synonyms which also appear in some definitions.

In the second part of the research the participants were asked about the extent to which American society was sensitive to issues related to physical appearance. Most of the participants responded affirmatively, but they put forward different evaluations of the degree to which this was so. Their feedback on linguistic expressions that they would use instead of the offensive term 'fat' shows significant similarities. In the part of the questionnaire where the participants were asked to do the same for the linguistic expressions entered as euphemisms under 'obesity' in Holder (2002), it was observed that many expressions would not be used by the participants, which suggests that they might be regarded as dysphemisms. Furthermore, it has also been observed that some expressions were more closely associated with the female or male gender. In some cases such associations overlap with Holder's (2002) comments regarding the application of certain expressions to a specific gender, and in some cases this was not so.

The answers of the German participants show that the speakers themselves are unclear regarding the words that can be used as euphemisms, although they stated that the German and Austrian societies were highly sensitive about the ways in which obese people are referred to. The online dictionaries investigated in this work mostly do not provide information 
regarding the stylistic usage of these words. They merely list synonyms which contain both euphemisms and dysphemisms.

In some cases it might be rather difficult to draw a line between euphemisms and dysphemisms, and that is why we have to resort not only to lexicographers' treatment of different linguistic expressions, but also to native speakers' intuition and evaluations. This is especially relevant in the contemporary context, where an increase in various forms of social media offers new virtual spaces where one has the opportunity to remain anonymous and refer to other individuals by using different expressions. Hopefully, the research conducted for the purpose of this paper has shed some further light on how both of these approaches might be used to distinguish between the euphemisms and dysphemisms that are used to refer to a particular aspect of physical appearance. Further research on the topic might include a greater number of participants, whose evaluations of linguistic items as euphemisms or dysphemisms would be taken into consideration. On the other hand, future research might also include different types of spoken and written texts, in which case the context of use might be taken into consideration in the evaluation of linguistic items as euphemisms or dysphemisms.

\section{References}

Allan, Keith, and Kate Burridge. 1991. Euphemism \& Dysphemism: Language Used as Shield and Weapon. New York: Oxford University Press.

—. 2006. Forbidden Words: Taboo and the Censoring of Language. Cambridge: Cambridge University Press.

Burridge, Kate. 2012. "Euphemisms and Language Change: The Sixth and Seventh Ages." Lexis: Journal in English Lexicology 7: 65-92. https://doi.org/10.4000/lexis.355.

Burridge, Kate, and Réka Benczes. 2019. “Taboo as a Driver of Language Change.” In The Oxford Handbook of Taboo Words and Language, edited by Keith Allan, 180-98. Oxford: Oxford University Press.

Casas Gómez, Miguel. 2018. "Lexicon, Discourse and Cognition: Terminological Delimitations in the Conceptualizations of Linguistic Taboo.” In Linguistic Taboo Revisited: Novel Insights from Cognitive Perspectives, edited by Andrea Pizarro Pedraza, 13-31. Berlin and Boston: De Gruyter.

Crespo Fernández, Eliecer. 2007. El eufemismo y el disfemismo: Procesos de manipulación del tabú en el lenguaje literario inglés. Alicante: Universidad de Alicante.

Cruse, Alan D. 2000. Meaning in Language: An Introduction to Semantics and Pragmatics. New York: Oxford University Press.

Duden Online, accessed January 29, 2019, https://www.duden.de.

DWDS - Digitales Wörterbuch der deutschen Sprache, accessed January 29, 2019, https://www.dwds.de. Grgić, Ana, and Davor Nikolić. 2011. “Antonomazija - figura kulturnoga pamćenja.” Fluminensia 23 (2): $129-42$.

Havers, Wilhelm. 1946. Neuere Literatur zum Sprachtabu. Wien: R.M. Rohrer.

Herrero Ruiz, Javier. 2009. Understanding Tropes: At the Crossroads between Pragmatics and Cognition. Frankfurt am Main: Peter Lang.

Holder, R. W. 2002. How Not to Say What You Mean: A Dictionary of Euphemisms. $3^{\text {rd }}$ ed. New York: Oxford University Press.

Keyes, Ralph. 2010. Euphemania: Our Love Affair with Euphemisms. New York: Little, Brown and Company.

Kuna, Branko. 2007. “Identifikacija eufemizama i njihova tvorba u hrvatskom jeziku.” Fluminensia 19 (1): 95-113.

Oxford English Dictionary. Accessed January 16, 2019. https://en.oxforddictionaries.com/english. Palmer, Frank R. 1981. Semantics: A New Outline. $2^{\text {nd }}$ ed. Cambridge: Cambridge University Press. 
Pasini, Dinka. 2005. "Eufemizmi u Anićevu rječniku." Fluminensia 17 (2): 59-66.

Pieper, Ursula. 1991. "Worüber man nur 'anders' spricht." Sprachreport 4: 5-7.

Rocco, Goranka. 2015. "Euphemismen und Dysphemismen im Flexibilisierungsdiskurs. Auf dem Weg zu einem mehrperspektivischen Untersuchungsdesign.” Lingue e Linguaggi 13: 257-75. https://doi.org /10.1285/i22390359v13p257.

Sawerschel, Hans. 2001. “Euphemismen bereichern die Sprache.” Sprachspiegel 57: 18-20. https://doi .org/ 10.5169/seals-422156.

Schröder Hartmut. 2013. Der Tabu-Komplex - Kultursemiotische Überlegungen. https://jelinektabu .univie.ac.at/tabu/forschungsfeld-tabu/hartmut-schroeder.

Textor, A. M. 2002. Sag es treffender. Überarbeitet von Renate Morell. Essen: Verlag Ernst Heyer.

Urban Dictionary, s.v. "Thicc," by That0neguy23, accessed August 30, 2017, https://www.urbandictionary .com/define.php?term=Thicc.

Warren, Beatrice. 1992. "What Euphemisms Tell Us about the Interpretation of Words." Studia Linguistica 46 (2): 128-72. https://doi.org/10.1111/j.1467-9582.1992.tb00833.x.

Yang, Ada Ya-ying, and Shelley Ching-yu Depner. 2016. "Euphemisms in Animal-Fixed Expressions in Mandarin Chinese." In Embodiment in Language (II): Food, Emotion and Beyond, edited by Shelley Ching-yu Depner, 93-108. Singapore: Springer. 